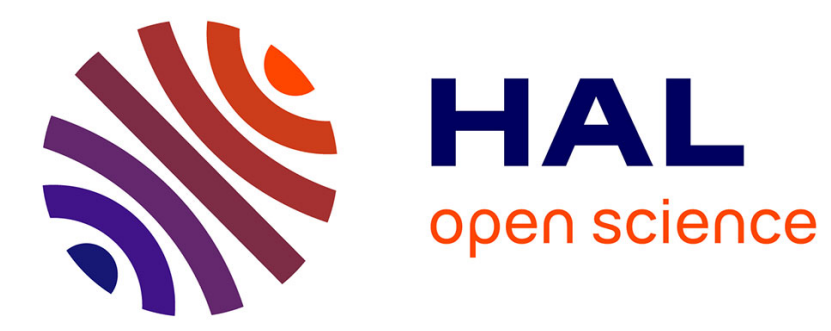

\title{
Investment-saving comovement under endogenous fiscal policy
}

\author{
Daniel Levy
}

\section{To cite this version:}

Daniel Levy. Investment-saving comovement under endogenous fiscal policy. Open Economies Review, 1995, 6 (3), pp.237-254. 10.1007/BF01000083 . hal-02382789

\section{HAL Id: hal-02382789 \\ https://hal.science/hal-02382789}

Submitted on 27 Nov 2019

HAL is a multi-disciplinary open access archive for the deposit and dissemination of scientific research documents, whether they are published or not. The documents may come from teaching and research institutions in France or abroad, or from public or private research centers.
L'archive ouverte pluridisciplinaire HAL, est destinée au dépôt et à la diffusion de documents scientifiques de niveau recherche, publiés ou non, émanant des établissements d'enseignement et de recherche français ou étrangers, des laboratoires publics ou privés. 


\title{
Investment-Saving Comovement under Endogenous Fiscal Policy
}

\author{
by \\ Daniel Levy \\ Department of Economics \\ Emory University \\ Atlanta, GA 30322-2240
}

JEL Classification: F41, E62, H39

Key Words: Feldstein-Horioka Puzzle, Investment, Saving, Capital Mobility, Endogenous Fiscal Policy

\begin{abstract}
:
I expand Feldstein's (1983) model by including flexible exchange rate and by introducing endogenous fiscal policy. Using this model, I demonstrate how a positive investmentsaving correlation can arise in a world with endogenous fiscal policy. I show that this correlation does not depend on capital mobility and therefore is compatible with any degree of capital mobility. This implies that the observed investment-saving comovement is not necessarily due to imperfect capital mobility. The model has a testable implication: it predicts a lack of Granger causality from private saving to private investment. Empirical examination of this prediction indicates that U.S. time series data is compatible with the hypothesis of endogenous fiscal policy during a flexible exchange rate period, but not during a fixed exchange rate period.
\end{abstract}


In a closed economy, private investment can only be financed by domestic saving and therefore investment and saving will be correlated. However, in an open economy, at least part of the investment can be financed by foreign saving. Therefore, in an open economy, national saving and investment may in principle diverge and move independently of each other. However, the empirical findings by Feldstein and Horioka (1980) and Feldstein (1983) indicate that investment and saving are highly correlated across countries. They interpret these findings as evidence of a lack of perfect capital mobility. ${ }^{1}$ This interpretation of the investment-saving comovement has been very controversial and a significant number of studies disagree with it since it is in contrast with the general deregulation of capital markets and increased integration of world financial markets that took place over the last 20-30 years. ${ }^{2}$

Several authors, like Tobin (1983), Westphal (1983), Roubini (1988), and Summers (1988), have offered an alternative explanation for the investment-saving comovement. If the government is concerned about balancing a current account deficit, it can set the size of its spending (or its budget deficit) endogenously by reacting to the gap between private saving and investment. If the government uses such an endogenous fiscal policy, then private investment and national saving will also be correlated; i.e., this will be true regardless of the degree of capital mobility.

From a theoretical point of view, standard macroeconomic theory assigns the government budget an exogenous policy role. However, its discretionary use by governments for stabilization purposes implies that policy makers actually react to events and situations occurring in the economy. This makes fiscal policy endogenous. In the new classical framework fiscal policy is treated in a similar manner except that the emphasis is on unanticipated implementation of the policy. ${ }^{3}$

Whether the government's budget policy is exogenous or endogenous is important because of its policy implications in the context of investment-saving correlation: Feldstein and Horioka's finding that variations in saving are associated with variations in investment, implies that under exogenous fiscal policy a reduction in the U.S. budget deficit will not improve external balance, rather it will increase investments. This conclusion, however, is not necessarily correct if fiscal policy is endogenous in the sense described above. ${ }^{4}$

In this paper I present a variant of a standard neoclassical model modified for a large open economy with flexible exchange rates. Using the model, I analyze the implications of perfect capital mobility and immobility for the investment-saving relationship and the crowding out effects of expansionary fiscal policy on investment and trade balance.

The model presented here is an extension of the model discussed in Feldstein (1983). The present model expands beyond Feldstein's model by explicitly introducing the market for foreign 
exchange as well as by addressing the role of fiscal policy in the context of investment-saving comovement. Unlike Feldstein (1983), who implicitly assumes that fiscal policy is exogenous, I allow for the possibility of endogeneity in the conduct of fiscal policy.

The model demonstrates how a positive investment-saving correlation can arise in a world with endogenous fiscal policy. Since this correlation does not depend on capital mobility and is therefore compatible with any degree of capital mobility, I conclude that tests of capital mobility that are based on investment-saving correlation are not likely to be informative about the true degree of capital mobility.

I also discuss testable implications of the model. In particular, I show that an endogenous fiscal policy hypothesis of the type considered in this paper predicts a lack of Granger causality from private saving to private investment. Empirical examination of this prediction indicates that the U.S. time series data is compatible with the hypothesis of endogenous fiscal policy during a flexible exchange rate period, but not during a fixed exchange rate period. The implication is that the observed investment-saving correlation in the U.S. time series may indeed be a result of an endogenous fiscal policy.

The paper is organized as follows. Section 1 describes the structure of the model. In Section 2 the implications of the model are analysed under the assumption of exogenous fiscal policy. In Section 3, the implications of the model are analysed under the assumption of endogenous fiscal policy. In Section 4, testable implications of the model are empirically examined using the U.S. time series data. The paper ends with conclusions.

\section{The Model}

Following Feldstein (1983), assume that the demand for gross domestic investment, $I$, is a decreasing function of real interest rate, $r$ :

$$
I=I(r)+\xi \quad I^{\prime}<0
$$

where $\xi_{l}$ is a zero mean random term with constant variance. Supply of private saving, $P S$, is an increasing function of the real interest rate:

$$
P S=S(r)+\xi_{s} \quad S^{\prime}>0
$$

where $\xi_{s}$ is a zero mean random term with constant variance. I assume that the correlation between $\xi_{1}$ and $\xi_{s}$ is zero. I make this assumption in order to focus on the role of fiscal policy in 
generating investment-saving comovement. Otherwise we need to address a possibility of a "common cause" mechanism, which is beyond the scope of this paper.

Exports, $X$, and imports, $M$, depend on the real exchange rate, $R$, and are given by (3) and (4):

$$
\begin{array}{ll}
X=X(R)+\xi_{X} & X^{\prime}>0 \\
M=M(R)+\xi_{M} & M^{\prime}<0
\end{array}
$$

where $\xi_{X}$, and $\xi_{M}$ are random shocks with zero mean and constant variance. From national income accounting, net exports, $N X$, equal net capital outflow (net foreign investment), $F$, which in turn is defined as capital outflow, $F_{c}$, minus capital inflow, $F_{l}$, and is a decreasing function of the real interest rate. Thus,

$$
F=F_{o}-F_{i}=F(r)+\xi_{F} \quad F^{\prime} \leq 0
$$

where $\xi_{F}$ is a zero mean random term with constant variance. In case of perfect capital mobility, $F^{\prime}=-\infty$, and if capital is completely immobile, then $F^{\prime}=0$.

\section{Exogenous Fiscal Policy}

Now assume that the government's receipts are fixed at $T_{0}$, and that the expenditures, $G$, are set exogenously. The budget deficit is given by

$$
G-T=G_{0}+\xi_{G}-T_{0}
$$

where $\xi_{G}$ is a fiscal policy shock. The model is closed by the national income identity

$$
[P S-(G-T)]-I=X-M
$$

which states that the excess of national saving over investment must match the trade balance. Since $F=X-M$, (3), (4), and (5) imply that

$$
F(r)+\xi_{F}=X(R)+\xi_{X}-M(R)-\xi_{M}
$$

which after total differentiation and rearrangement, yields 


$$
d R=\frac{F^{\prime} d r-d \xi_{X}+d \xi_{M}+d \xi_{F}}{X^{\prime}-M^{\prime}}
$$

Since $X^{\prime}>0$, and $M^{\prime}<0$, the denominator in (9) is always positive. Therefore, equation (9) implies that

$$
\frac{d R}{d r}=\frac{F^{\prime}}{X^{\prime}-M^{\prime}} \leq 0
$$

That is, unless capital is completely immobile, an increase in interest rate $(d r>0)$ will lead to a lower exchange rate since the resulting capital inflow will cause an appreciation of the domestic currency. It also implies that a positive (negative) shock to imports (exports) devalues domestic currency since it results in higher (lower) demand for (supply of) foreign currency.

Now substitute (1), (2), (3), (4), and (6) into (7) to get

$$
S(r)+\xi_{s}-G_{0}-\xi_{G}+T_{0}-I(r)-\xi_{I}=X(R)+\xi_{X}-M(R)-\xi_{M}
$$

Taking the total differential of (10), and using (9) for $d R$, yields

$$
d r=\frac{d \xi_{I}+d \xi_{G}-d \xi_{S}+d \xi_{F}}{S^{\prime}-I^{\prime}-F^{\prime}}
$$

Since $S^{\prime}>0, I^{\prime}<0$, and $F^{\prime} \leq 0$, the denominator in (11) is always positive. The equation states that as long as capital is not perfectly mobile (i.e., $F^{\prime}>-\infty$ ), the interest rate rises when there is a positive shock to either investment $\left(d \xi_{I}>0\right)$, government expenditures $\left(d \xi_{G}>0\right)$, or demand for net foreign investment $\left(d \xi_{F}>0\right)$. However, if capital is perfectly mobile (i.e., $\left.F^{\prime}=-\infty\right)$, then either shock will instantaneously result in capital inflow, completely satisfying the excess demand for resources, and thus leaving the interest rate unchanged.

Substituting (11) into (9), gives $d R$ in terms of all the possible shocks of the model:

$$
d R=F\left[\frac{d \xi_{I}+d \xi_{G}-d \xi_{s}+d \xi_{F}}{\left(X^{\prime}-M^{\prime}\right)\left(S^{\prime}-I^{\prime}-F^{\prime}\right)}\right]+\frac{d \xi_{M}-d \xi_{X}+d \xi_{F}}{X^{\prime}-M^{\prime}}
$$

Note that both denominators in equation (12) are positive. Taking the total differential of (5) and combining it with (11) yields

$$
d F=F^{\prime} d r+d \xi_{F}=F^{\prime}\left[\frac{d \xi_{I}+d \xi_{G}-d \xi_{s}+d \xi_{F}}{S^{\prime}-I^{\prime}-F^{\prime}}\right]+d \xi_{F}
$$


which shows the response of net capital outflow ( or net foreign investment), and thus of trade balance, to various shocks. Equations (12) and (13) can be used jointly for comparative statics under alternative hypotheses about capital mobility. For example, with perfect capital mobility (i.e., $\left.F^{\prime}=-\infty\right)$, an increase in government spending $\left(d \xi_{G}>0\right)$ causes a decrease in net foreign investment $(F)$ "one for one" and therefore results in capital inflow since

$$
\lim _{F^{\prime} \rightarrow-\infty} \frac{d F}{d \xi_{G}}=-1
$$

Simultaneously,

$$
\lim _{F^{\prime} \rightarrow-\infty} \frac{d R}{d \xi_{G}}=-\frac{1}{X^{\prime}-M^{\prime}}<0
$$

which means that domestic currency appreciates reducing the external balance. In other words, an expansionary fiscal policy completely crowds out net exports, but has no effect on the interest rate as

$$
\lim _{F^{\prime} \rightarrow-\infty} \frac{d r}{d \xi_{G}}=0
$$

At the other extreme, if capital is completely immobile $\left(F^{\prime}=0\right)$, then the increased government demand must be satisfied by domestic resources. The first term on the right hand side of (12) and (13) vanishes when $F^{\prime}=0$. Therefore, an expansionary fiscal policy leaves the current account and the exchange rate unchanged and instead increases the interest rate since

$$
\lim _{F^{\prime} \rightarrow 0} \frac{d r}{d \xi_{G}}=\frac{1}{S^{\prime}-I^{\prime}}>0
$$

This leads to a crowding out of investment because

$$
\lim _{F^{\prime} \rightarrow 0} \frac{d I}{d \xi_{G}}=\frac{I}{S^{\prime}-I^{\prime}}<0
$$

as can be seen from equation (14) below. Using a similar argument, it follows that under partial capital mobility, (i.e., $0>F^{\prime}>-\infty$ ), a higher budget deficit will crowd out both investment as well as net export.

In order to see the relationship between investment and national saving, take the total derivative of (1) and use (11) to get 


$$
d I=I^{\prime} d r+d \xi_{I}=I^{\prime}\left[\frac{d \xi_{I}+d \xi_{G}-d \xi_{S}+d \xi_{F}}{S^{\prime}-I^{\prime}-F^{\prime}}\right]+d \xi_{I}
$$

which means that

$$
\frac{d I}{d \xi_{s}}=-\frac{I^{\prime}}{S^{\prime}-I-F^{\prime}}
$$

Under perfect capital mobility,

$$
\lim _{F^{\prime} \rightarrow-\infty} \frac{d I}{d \xi_{s}}=0
$$

and so any change in domestic private saving (which changes national saving by an equal amount since government saving is exogenous) is matched by a corresponding change in capital flow, leaving investment unchanged. Thus under perfect capital mobility, investment and national saving will not be correlated. If capital is immobile, however, i.e., if $F^{\prime}=0$, then

$$
\lim _{F^{\prime} \rightarrow 0} \frac{d I}{d \xi_{s}}=-\frac{I^{\prime}}{S^{\prime}-I^{\prime}}
$$

and therefore $0<\frac{d I}{d \xi_{s}} \leq 1$. That is, higher national saving will lead to higher investment. It is this result that led Feldstein and Horioka (1980) to interpret the positive investment-saving relationship they found as an indicator of a lack of perfect capital mobility.

\section{Endogenous Fiscal Policy}

Now consider a situation where the government has a reaction function through which it responds to current account imbalances by adjusting its spending according to the gap between private saving and investment. In particular, suppose that fiscal policy reaction function is given by

$$
G-T=\left[\alpha(P S-I)+\xi_{G}\right]-T_{0}
$$

where $0<\alpha \leq 1$. Substituting (1), (2), (3), (4), and (16) into (7), taking its total derivative, and using (9) for $d R$ yields

$$
d r=\frac{(1-\alpha)\left(d \xi_{s}-d \xi_{I}\right)-d \xi_{F}-d \xi_{G}}{(1-\alpha)\left(I^{\prime}-S^{\prime}\right)+F^{\prime}}
$$


Here, if the government follows an endogenous fiscal policy of the type assumed in (16), then investment and national saving will be correlated even if capital is perfectly mobile. Therefore, the observed positive correlation between investment and private saving is not necessarily an indicator of a lack of perfect capital mobility. To see this, suppose that there is a positive change in private saving. i.e., $d \xi_{s}>0$. Such a change will be followed by an adjustment of the government's budget deficit according to (16). To get the exact expression, take the total derivative of (16), replace $d r$ by (17), and find $d(G-T)$. This yields

$$
\begin{aligned}
d(G-T) & =\alpha\left(S^{\prime}-I^{\prime}\right) d r+\alpha d \xi_{s}-\alpha d \xi_{I}+d \xi_{G} \\
& =\alpha\left(S^{\prime}-I^{\prime}\right)\left[\frac{(1-\alpha)\left(d \xi_{s}-d \xi_{)}\right)-d \xi_{F}-d \xi_{G}}{(1-\alpha)\left(I^{\prime}-S^{\prime}\right)+F^{\prime}}\right]+\alpha d \xi_{S}-\alpha d \xi_{I}+d \xi_{G}
\end{aligned}
$$

When capital is perfectly mobile, i.e., $F^{\prime}=-\infty$, the first term on the right hand side of (18) vanishes and

$$
\frac{d(G-T)}{d \xi_{s}}=\alpha
$$

The total differential of national saving is given by

$$
d N S=\left[(1-\alpha) S^{\prime}+\alpha \eta d r+(1-\alpha) d \xi_{s}+\alpha d \xi_{I}-d \xi_{G}\right.
$$

and since $d r=0$ under perfect capital mobility, national saving will respond to the change in private saving by $\frac{d N S}{d \xi_{s}}=(1-\alpha)$. Note that in such an environment, private investment does not respond to changes in private saving. To see this, derive $\frac{d I}{d \xi_{s}}$ by taking the total differential of

(1) and substituting (17) for $d r$ :

$$
\frac{d I}{d \xi_{s}}=\frac{I^{\prime}(1-a)}{(1-\alpha)\left(I-S^{\prime}\right)+F^{\prime}}
$$

Under perfect capital mobility we get

$$
\lim _{F^{\prime} \rightarrow-\infty} \frac{d I}{d \xi_{s}}=0
$$

Thus, this model makes a testable prediction: it predicts a lack of Granger causality from private saving to investment. However, national saving responds to changes in investment since 
$\frac{d N S}{d \xi_{I}}=\alpha$, which does not depend on $F^{\prime}$. Hence, in the case of endogenous fiscal policy, investment and national saving will be correlated no matter what the degree of capital mobility is.

Note that the crowding out effect of fiscal policy here will be similar to the effect when fiscal policy is exogenous. To see this, substitute (17) into (9) to get

$$
d R=F\left\{\frac{(1-\alpha)\left(d \xi_{s}-d \xi_{)}\right)-d \xi_{F}-d \xi_{G}}{\left(X^{\prime}-M^{\prime}\right)\left\lceil(1-\alpha)\left(I^{\prime}-S^{\prime}\right)+F^{\prime}\right\rceil}\right]+\frac{d \xi_{M}-d \xi_{X}+d \xi_{F}}{X^{\prime}-M^{\prime}}
$$

which implies that under perfect capital mobility

$$
\lim _{F^{\prime} \rightarrow-\infty} \frac{d R}{d \xi_{G}}=\lim _{F^{\prime} \rightarrow-\infty}\left[-\frac{F^{\prime}}{\left(X^{\prime}-M^{\prime}\right)\left[(1-a)\left(I-S^{\prime}\right)+F^{\prime}\right]}\right]<0
$$

by L'Hôspital's rule. Therefore, expansionary fiscal policy leads to an appreciation of domestic currency and consequently causes a crowding out of net exports. Since under perfect capital

mobility $d r=0$ from (17), $\frac{d I}{d \xi_{G}}=0$ and fiscal policy will have no effect on investment.

However, if capital is immobile, then $\frac{d R}{d \xi_{G}}=0$, while

$$
\frac{d I}{d \xi_{G}}=-\frac{I^{\prime}}{(1-\alpha)\left(I^{\prime}-S^{\prime}\right)}<0
$$

so we get a crowding out of investment.

In summarize, the model presented here shows that a positive correlation between domestic private investment and national saving is compatible with both, exogenous as well as endogenous fiscal policy. In case of exogenous fiscal policy, under perfect capital mobility, domestic investment and national saving are not correlated, while under immobile capital they tend to move together. If fiscal policy is endogenous, then domestic investment and national saving will be correlated even if capital is perfectly mobile. In such case, an observed strong correlation between national saving and domestic investment will not necessarily indicate a lack of perfect capital mobility. This hypothesis has a testable implication: it predicts a lack of Granger causality from private saving to investment.

\section{Granger Causality and Cointegration Test Results}

As was shown in Section 4, the hypothesis of endogenous fiscal policy of the type assumed in this paper predicts a lack of Granger causality from private saving to investment. As a test of this implication I run a bivariate Granger causality test between time series of gross 
private saving and gross private domestic investment using U.S. annual data covering the period 1929-89. The data for the 1929-82 period is taken from the NIPA tables of the BEA. For the 1983-89 period the data come from the Economic Report of the President (1990). The series are measured in 1982 dollars. The plots of the time series of domestic investment and private saving are shown on Figure 1.

The Granger causality test equation is given by

$$
I_{t}=\alpha+\sum_{n=1}^{4} \beta_{n} I_{t-n}+\sum_{n=1}^{4} \gamma_{n} P S_{t-n}+\varepsilon_{t}
$$

where $I_{1}$ denotes gross private domestic investment and $P S_{t}$ denotes gross private saving. The null hypothesis is that private investment is not Granger-caused by private saving. Technically, this is tested by examining whether or not $\gamma_{n}=0$ for each $n$ simultaneously.

The results are reported in Table 1. I run the causality test for the entire sample period as well as for two sub-periods, which correspond to periods of fixed and flexible exchange rate regimes, respectively. According to the results, the null hypothesis cannot be rejected for the entire sample period. The null hypothesis cannot be rejected also for the second subperiod, but it is rejected at the 5\% level of significance for the first subperiod. This means that the data is compatible with the hypothesis of endogenous fiscal policy during a flexible exchange rate period, but not during a fixed exchange rate period. Obviously, these findings do not prove that fiscal policy was endogenous over 1973-89 period because a lack of Granger causality from private saving to private investment could in principle be a consequence of other types of policies. For comparison purposes it should be mentioned that Summers (1988) and Bayoumi (1990), using a cross-section data of OECD and ten industrial countries, respectively, find that an endogenous fiscal policy of the type modelled here might be playing an important role in generating the positive investment-saving comevement obsereved in the data of open economies.

It is possible to verify these Granger causality test results by considering a cointegration relationship between domestic investment and private saving. ${ }^{5}$ According to the ErrorCorrection Representation Theorem proved by Engle and Granger (1987), the concepts of cointegration and Granger causality are directly related. Specifically, they show that if two series are cointegrated, then there should be a Granger causality between these series at least in one direction. Thus, by examining the cointegration property of the investment-saving comovement, we can check whether the Granger-causality test results are consistent with cointegration tests.

Several authors have examined the cointegration relationship between investment and saving using the U.S. time series data. See for example Miller (1988), Otto and Wirjanto 
(1989), Leachman (1991), Gulley (1992), and Levy (1994). All these authors, however, focus their attention on the relationship between the time series of national saving and domestic investment. Here I am interested in examining the relationship between private saving and domestic investment. 6

To test for cointegration, we first need to establish unit root properties of the time series of private saving and domestic investment. To determine whether private saving and domestic investment series are stationary, we examine each series for a presence of unit roots using the Augmented Dickey-Fuller tests of the form

$$
\Delta x_{t}=\alpha_{0}+\alpha_{1} t+\gamma x_{t-1}+\sum_{i=1}^{4} \phi_{i} \Delta x_{t-i}+\varepsilon_{l}
$$

where $x_{t}$ is the series we are examining and $t$ is a linear time trend. The null hypothesis is that $\gamma=0$, which means that the series contains an unit root and is thus nonstationary, i.e., $x_{t} \sim I(1)$. The alternative hypothesis is that the series are stationary, that is, $x_{t} \sim I(0)$.

Initially, we test the hypothesis of an unit root in the series measured in levels. The results are reported in the first column of Table 2. As the values of the Augmented Dickey-Fuller $t$ statistics indicate, the hypothesis of nonstationarity cannot be rejected for domestic investment (denoted $I$ ) and private saving (denoted $P S$ ). Next, we test whether the first differences of the series are nonstationary. The figures presented in the last column of Table 2 indicate that the hypothesis of an unit root in the differenced series can be rejected. ${ }^{7}$ Therefore, we conclude that private saving and domestic investment series are $I(1)$, and thus can be represented as difference stationary processes. The results reported by Miller (1988), Otto and Wirjanto (1989), Leachman (1991), Gulley (1992), and Levy (1994) on the unit root properties of domestic investment in the U.S. are essentially identical to what I report here.

To test for cointegration between the time series of private saving and domestic investment, I use Johansen's (1988) maximum likelihood method which seems to have better statistical properties than the more commonly used Engle-Granger (1987) two-step method. Below I define the test statistics used in this approach. For a detailed description of Johansen's maximum likelihood method, see Johansen's original article or Banerjee et al. (1993).

Johansen (1988) proposes two tests for estimating the number of cointegrating vectors. The first, called maximal eigenvalue test, is given by the statistic

$$
\lambda_{\max }=-n \log \left(1-\lambda_{r}\right)
$$


where $n$ is the number of observations, and $\lambda_{r}$ is the $r$-th eigenvalue determined by solving the determinantal equation associated with the residual product moment matrix constructed using the residuals' matrices. The maximal eigenvalue test is designed to test $H(r-1)$ against $H(r)$. That is, the null hypothesis is that there are $(r-1)$ cointegrating vectors against the alternative of $r$.

The second test, called trace test, is designed for testing $H(r)$ against $H(m)$, where $r<m$. The trace statistic is given by

$$
J_{T}=-n \sum_{i=r+1}^{m} \log (1-\lambda \hat{j})
$$

The cointegration test results are presented in Table 3. The critical values I use are taken from Osterwald-Lenum (1992). ${ }^{8}$ In estimating the cointegration vectors I use VAR(4).

In Johansen's framework the number of cointegrating vectors is determined sequentially. We start with the hypothesis that there are no cointegrating relations, that is, $r=0$. We continue only if this hypothesis is rejected. In that case we test the hypothesis that there is at most one cointegrating vector $(r \leq 1)$, and so on. The test results can be interpreted in favor of cointegration only if $0<r<m$. Full rank, that is $r=m$, only indicates that the process is stationary.

Following this sequential procedure, we find that the time series of domestic investment and private saving are cointegrated only during the 1929-72 period (with one cointegrating vector, i.e., $r=1$ ). To see this, look at the middle part in Table 3: the values of both test statistics, $\lambda_{\max }=12.79$ and $J_{T}=13.40$, are slightly bigger than the corresponding $10 \%$ critical values. Therefore, the null of no cointegrating vectors $(r=0)$ is rejected in favour of the alternative with $10 \%$ significance. Now we proceed to the next hypothesis, $r \leq 1$. Here we see that both test statistics ( 0.31 and 0.31$)$ are below the corresponding critical values. ${ }^{9}$ Therefore the null of one or less cointegrating vectors, $(r \leq 1)$, cannot be rejected. Since the hypothesis of zero cointegrating vector was rejected in the preceding stage, we conclude that $r=1$. That is, domestic investment and private saving are cointegrated with one cointegrating vector.

During the sample periods 1929-89 and 1973-89, the test statistics are not statistically significant in the first stage of the testing. Therefore the null of zero cointegrating vectors $(r=0)$ cannot be rejected for these periods. That is, domestic investment and private saving are not cointegrated for these sample periods. Thus, we find that the series are cointegrated during fixed exchange rate period, but not during flexible exchange rate period. Miller (1988) reports similar findings for the time series of national saving and domestic investment.

These findings are consistent with Granger causality test results reported above. This is 
because a cointegration relationship between the two series implies Granger causality at least in one direction. Indeed, for the 1929-72 period where we find an evidence of cointegration, we rejected the null of no Granger causality from private saving to domestic investment. For the other two sample periods, 1929-89 and 1973-89, we find that the two series are not cointegrated. And the finding that there is no Granger causality during these sample periods is clearly consistent with the cointegration test results. ${ }^{10}$

An additional implication of the observed cointegration of domestic investment and private saving during the fixed exchange rate period can be derived by looking at the national income accounting identity given in equation (7), which can be rewritten as

$$
P S-I=[(X-M)+(G-T)] .
$$

If $P S$ and $I$ are cointegrated, then their linear combination given on the left hand side of equation (26) should be stationary. ${ }^{11}$ Consequently, the right hand side of (26), which is a sum of budget deficit and current account balance, should also be stationary during the fixed exchange rate period. On the other hand, during the periods of no cointegration, 1929-89 and 1973-89, we expect this sum to be nonstationary.

To examine the empirical validity of this prediction, I have applied Augmented DickeyFuller unit root test to the $[(X-M)+(G-T)]$ series. The results reported in Table 2 indicate that the unit root tests are not fully consistent with the cointegration test results. During the 1929-89 and 1973-89 periods the $[(X-M)+(G-T)]$ series are nonstationary (the null of unit root cannot be rejected) as predicted by cointegration test results. However, it is nonstationary also during the 1929-72 period which is inconsistent with the finding that domestic investment and private saving are cointegrated during that period.

\section{Conclusions}

In this paper I expand the standard neoclassical open economy model by introducing endogenous fiscal policy. Using the model, I demonstrate analytically how a positive investment-saving correlation can arise in a world with endogenous fiscal policy. I also show that this correlation does not depend on capital mobility and therefore is compatible with any degree of capital mobility. This means that the observed investment-saving comovement in the U.S. time series data does not necessarily imply imperfect capital mobility. The hypothesis of endogenous fiscal policy predicts a lack of Granger causality from private saving to investment. Empirical examination of this prediction indicates that the U.S. time series data of private saving 
and investment is compatible with the hypothesis of endogenous fiscal policy during a flexible exchange rate period, but not during a fixed exchange rate period.

The implication is that the investment-saving comovement observed in the U.S. time series data may indeed be due to an endogenous fiscal policy, where the government is trying to balance the current account by setting its budget plans according to the gap between private saving and investment.

How can we explain the differences in results between the fixed and flexible exchange rate periods? One possibility is that during fixed exchange rate period investment and saving were cointegrated simply because capital was not very mobile. The abandonment of the Breton Wood system and the elimination of capital controls in the early 1970s along with the increased integration of worlds financial markets during the last 20 years may have led to an increased international capital mobility which eliminated the long-run (i.e., cointegration) relationship between investment and saving.

An alternative explanation may be given along the lines suggested in this paper. That is, it is possible that the government's fiscal policy was indeed endogenous during the flexible exchange rate period, but not during fixed exchange rate period. Note that in the context of the model presented in the paper, what I have in mind is a very specific form of endogeneity: the government reacts to current account imbalances by adjusting its budget balance according to the gap between private saving and investment.

In general it may be argued that this kind of policy is more plausible during fixed, rather than flexible exchange rate periods as Miller (1988) suggests. An examination of the U.S. trade deficit development over the last 10-15 years, however, suggests the opposite. The continuous appreciation of the dollar during the 1980s has led to a large trade and current account deficits which was viewed by many observers and administration officials as a cause for great concern. The increase in trade deficit led to a loss of exports and substitution of imports for domestic production. Consequently, there was a significant pressure on policy makers from the affected industries to reduce the trade deficit. Therefore, an endogenous fiscal policy was a rather likely scenario for the U.S. during the flexible exchange rate period. ${ }^{12}$ Summers (1988) and Bayoumi (1990) reach a similar conclusion using cross-country data, which includes the U.S.

An extension of this study tries to evaluate the empirical validity of the endogenous fiscal policy hypothesis by directly estimating a fiscal policy reaction function of the type considered in this paper using U.S. time series data. Although preliminary results suggest that the hypothesis of endogenous fiscal policy cannot be rejected, this question is still under investigation. 


\section{Notes}

1. Studies that expand Feldstein and Horioka's analysis to different time periods and samples, include Caprio and Howard (1984), Murphy (1984), Obstfeld (1986a, 1986b), and Wong (1988).

2. See, e.g., Tobin (1983), Westphal (1983), Obstfeld (1986a, 1986b), Frankel and MacArthur (1988), Ghosh (1990), Tesar (1991), and Baxter and Crucini (1993).

3. These studies often assume fiscal dominance, which means that fiscal authorities set their budget policy exogenously, and monetary authorities then have no choice but accommodate it. See, e.g., Sargent and Wallace (1981). From the empirical point of view, classification of government budget policy as exogenous or endogenous seems largely to depend on the hypothesis been tested. For example, Evans (1987), Ghosh (1990), and Moreno (1988) model government budget deficit as exogenous while Dooley et al. (1987), Fieleke (1982), and Pigott (1989) treat the budget policy as endogenous.

4. The "rule of thumb" published by Congressional Budget Office (1985, p. 75) suggests that government budget policy is endogenous in CBO's view.

5. I thank the anonymous referee for suggesting this idea.

6. Although Bayoumi (1990) examines the relationship between private saving and domestic investment, he does not use the cointegration methodology since he estimates cross-section regressions using data from ten industrial countries. Argimón and Roldán (1994) do examine the cointegration relationship between private saving and domestic investment but their data set does not include the U.S.

7. The unit root test results for the $[(X-M)+(G-T)]$ series are discussed below.

8. I choose not to use more commonly used critical values tabulated by Johansen and Juselius (1990) since Podivinsky (1990) shows that those critical values may be invalid for sample sizes of 100 or less.

9. The equality of these statistics is not a coincidence. In the final stage of sequential testing, their values always equal by construction of these tests.

10.However, it should be noted that an opposite result on Granger causality during these sample periods would not contradict cointegration test results either. This is because if there is no cointegration, then either one, Granger causality and Granger noncausality, are possible.

11.Actually, this analysis is based on the finding (not reported in Table 3) that the cointegrating vector is $[1,-1]$. Leachman (1991) reports a similar finding.

12.It should be mentioned, however, that setting the budget deficit according to the gap between private saving and investment is not the only way for reducing current account deficit. A reduction in a current account deficit can be accomplished also by means of monetary policy by affecting the exchange rate and thus the level of economic activity. Other possibilities include the use of investment tax credit, the adjustment of depreciation allowance schemes, etc. See Feldstein and Bacchetta (1989). 


\section{References}

Argimón, Isabel and José María Roldán (1994) “Saving, Investment, and International Capital Mobility in EC Countries,” European Economic Review, Vol. 38, 59-67.

Banerjee et al. (1993) Cointegration, Error-Correction, and the Econometric Analysis of NonStationary Data (Oxford: Oxford University Press).

Baxter, Marianne and Mario Crucini (1993) "Explaining Saving-Investment Correlations," American Economic Review, Vol. 83, No. 3, June, 416-436.

Bayoumi, Tamim (1990) "Saving-Investment Correlations: Immobile Capital, Government Policy, or Endogenous Behavior?" International Monetary Fund Staff Papers, June, Vol. 37, No, 2, 360-387.

Caprio, Gerard, Jr., and David H. Howard (1984) "Domestic Saving, Current Accounts, and International Capital Mobility," International Finance Discussion Paper No. 244 (Washington: Board of Governors of the Federal Reserve System), June.

Congressional Budget Office (1985), "The Economic and Budget Outlook: Fiscal Years 1986-1990," February.

Dooley, Michael, Jeffrey Frankel, and Donald J. Mathieson (1987) “International Capital Mobility: What Do Investment-Saving Correlations Tell Us?" International Monetary Fund Staff Papers, Vol. 34, September, 503-530.

Engle, Robert and Clive Granger (1987) "Cointegration and Error-Correction: Representation, Estimation, and Testing," Econometrica, Vol. 55, 251-276.

Engle, Robert and B. S. Yoo (1991) “Cointegrated Economic Time Series: A Survey with New Results," in Long-Run Economic Relationships: Readings in Cointegration, edited by Robert Engle and Clive Granger (Oxford University Press, New York), 237-266.

Evans, Paul (1987) "Interest Rates and Expected Future Budget Deficits in the United States," Journal of Political Economy, 95, February, 34-58.

Feldstein, Martin (1983), "Domestic Saving and International Capital Movement in the Long Run and the Short Run," European Economic Review, Vol. 21, 129-151.

Feldstein, Martin and Charles Horioka (1980) "Domestic Saving and International Capital Flows," The Economic Journal, Vol. 90, June, 314-329.

Feldstein Martin and Phillipe Bacchetta (1989) "National Saving and International Investment," 
Working Paper No. 3164, National Bureau of Economic Research.

Fieleke, N. (1982) "National Saving and International Investment," in Saving and Government Policy, Conference Series No. 25, Federal Reserve Bank of Boston, 138-157.

Frankel, Jeffrey A. and Alan T. MacArthur (1988), "Political vs. Currency Premia in International Real Interest Rate Differentials,” European Economic Review, Vol. 32, No. 5, June, 1083-1121.

Ghosh, Atish R. (1990), "International Capital Mobility and Optimal Current Account Behavior: An Empirical Investigation,” Discussion Paper No. 50, Department of Economics, Princeton University, February.

Gulley, O. David (1992) "Are Saving and Investment Cointegrated? Another Look at the Data," Economics Letters, Vol. 39, 55-58.

Johansen, Søren (1988) "Statistical Analysis of Cointegration Vectors," Journal of Economic Dynamics and Control, Vol. 12, 231-254.

Johansen, Søren and Katharina Juselius (1990) "Maximum Likelihood Estimation and Inference on Cointegration with Applications to the Demand for Money," Oxford Bulletin of Economics and Statistics, Vol. 52, 169-210.

Leachman, Lori (1991) "Saving, Investment, and Capital Mobility Among OECD Countries," Open Economies Review, Vol. 2, No. 2, 137-163.

Levy, Daniel (1991), "Investment-Saving Comovement, Capital Mobility, and Fiscal Policy," presented at the National Bureau of Economic Research, Universities Research Conference on Macroeconomic Effects of Fiscal Policy, March.

Levy, Daniel (1994), “Is Feldstein-Horioka Puzzle Really a Puzzle?” Working Paper, Department of Economics, Emory University, May, submitted.

MacKinnon, James G. (1991) "Critical Values for Cointegration Tests," in Long-Run Economic Relationships: Readings in Cointegration, edited by Robert Engle and Clive Granger (Oxford University Press, New York), 267-276.

Miller, Stephen M. (1988) “Are Saving and Investment Cointegrated?” Economics Letters, Vol. 27, 31-34.

Moreno, Ramon (1988) “Saving, Investment, and the U.S. External Balance," Economic Review, Federal Reserve Bank of San Francisco, Fall, No. 4, 3-17.

Murphy, Robert G. (1984), “Capital Mobility and Relationship between Saving and Interest 
Rates in OECD Countries," Journal of International Money and Finance, Vol. 3, 327-342.

Obstfeld, Maurice (1986a), "Capital Mobility in the World Economy: Theory and Measurement," Carnegie-Rochester Conference Series on Public Policy, Vol. 24, Spring, 55-104.

Obstfeld, Maurice (1986b), "How Integrated Are World Capital Markets: Some New Tests," National Bureau of Economic Research, Working Paper No. 2075.

Osterwald-Lenum, M. (1992) "Recalculated and Extended Tables of the Asymptotic Distribution of Some Important Maximum Likelihood Cointegration Test Statistics,” Working Paper.

Otto, Glenn and Tony Wirjanto (1989) "National Saving and Domestic Investment in the Long Run: Some Time Series Evidence for the U.S. and Canada," Working Paper No. 754, Institute for Economic Research, Queen's University.

Pigott, Charles (1989) "Economic Consequences of Continued U.S. External Deficits," Quarterly Review, Federal Reserve Bank of New York, Winter-Spring, 4-15.

Podivinsky, J. (1990) “Testing Misspecified Cointegrating Relationships,” Monash University Working Paper.

Roubini, Nouriel (1988), "Current Account and Budget Deficits in an Intertemporal Model of Consumption and Tax Smoothing," unpublished manuscript.

Sargent, Thomas J. and Neil Wallace (1981), "Some Unpleasant Monetarist Arithmetics," Quarterly Review, Federal Reserve Bank of Minneapolis, Fall, 1-17.

Summers, Lawrence (1988) "Tax Policy and International Competitiveness," in Jacob Frenkel, ed., International Aspects of Fiscal Policies, National Bureau of Economic Research Conference Report, (Chicago: Chicago University Press), 349-375.

Tesar, Linda (1991) “Saving, Investment, and International Capital Flows,” Journal of International Economics, Vol. 31, August, 55-78.

Tobin, James (1983) "Domestic Saving and International Capital Movements in the Long-Run and the Short-Run" by M. Feldstein: Comment, European Economic Review, Vol. 21 (March-April 1983), 153-156.

Westphal, Uwe (1983) "Domestic Saving and International Capital Movements in the Long-Run and the Short-Run" by M. Feldstein: Comment, European Economic Review, Vol. 21, (March-April ), 157-159.

Wong, David Y. (1988), "What Do Saving-Investment Relationships Tell Us about Capital Mobility?” Working Paper No. 88-10, Federal Reserve Bank of Philadelphia. 


\section{Acknowledgements}

I thank the anonymous referee, the editor, and an associate editor of this journal for helpful comments and suggestions. This paper is an extension of Chapter 1 of my Ph.D. dissertation. I thank my Ph.D. thesis committee members, Maxwell Fry, Jack Johnston, David Lilien, and Giovanna Mossetti for commenting on earlier drafts of this paper.

This paper is based on the University of California/Irvine Economics Working Paper No. 90-91-04 titled "Investment-Saving Comovement, Capital Mobility, and Fiscal Policy," which was presented at the 1991 National Bureau of Economic Research Conference on the Macroeconomic Effects of Fiscal Policy. I benefited from the comments made by the participants of that conference, including Andrew Abel, V.V. Chari, Robert Eisner, Robert E. Lucas, Jr., Assaf Razin, and especially by my discussants, Marianne Baxter and Maurice Obstfeld. An earlier version of this paper was also presented at Bar Ilan, Ben Gurion, Board of Governors, Emory, Indiana (Bloomington and Indianapolis), Louisiana State University, Northeastern, State University of New York at Albany, Tulane, Union, and University of California at Irvine. I am grateful to these seminar participants, especially to Martin J. Bailey, Betty Daniel, Fuku Kimura, Kajal Lahiri, David Smyth, Avia Spivak, and Jimmy Weinblatt for useful comments and suggestions. Finally, I thank Shomu Banerjee, Robert Carpenter, Robert Chirinko, Hashem Dezhbakhsh, and Robert Utz for useful comments and discussions. All errors are mine.

Address all correspondence to: Daniel Levy, Department of Economics, Emory University, Atlanta, GA 30322-2240, U.S.A. 


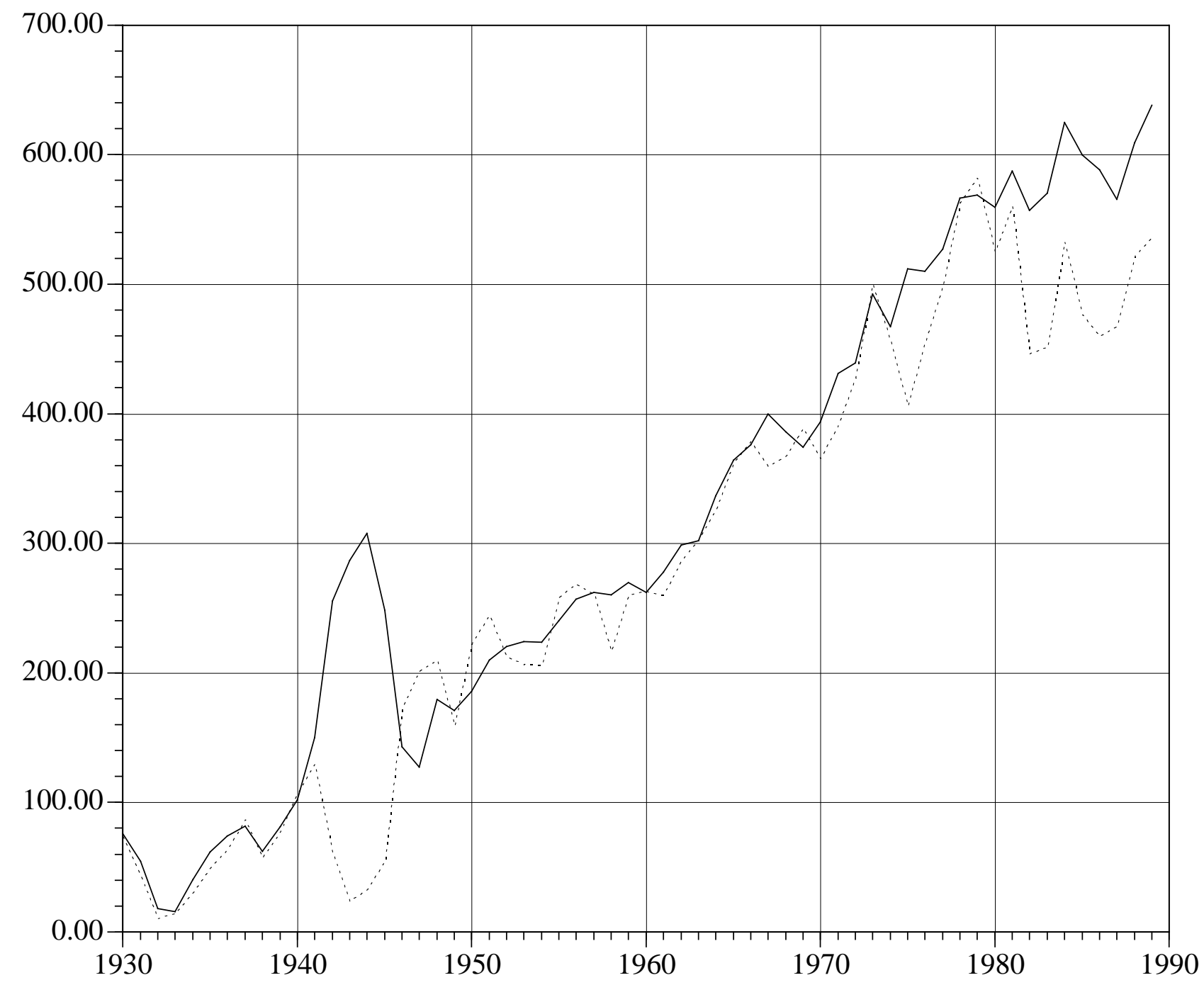

Private Saving

Domestic Investment

Figure 1 
Figure Legends

Figure 1. Private Saving and Domestic Investment, U.S., 1929-89, Billions of 1982 Dollars. (Source: National Income and Product Accounts of the U. S., Bureau of Economic Analysis, Department of Commerce, 1992.) 
Table 1. Granger Causality Test Results

\begin{tabular}{lccc}
\hline Sample Period & $F$-Statistic & $p$-value & Is the $\mathrm{H}_{0}$ rejected? \\
\hline $1929-89$ & 1.93 & 0.12 & No \\
$1929-72$ & $2.95^{b}$ & 0.03 & Yes \\
$1973-89$ & 0.47 & 0.75 & No \\
\hline
\end{tabular}

Note: The $\mathrm{H}_{0}$ hypothesis is that private investment is not Granger caused by private saving. Superscript $b$ indicates a $5 \%$ significance. 
Table 2. Unit Root Test Results

\begin{tabular}{|c|c|c|c|}
\hline \multirow[t]{2}{*}{ Period } & \multirow[t]{2}{*}{ Series } & \multicolumn{2}{|c|}{ Augmented Dickey-Fuller $t$-statistic } \\
\hline & & Levels & First differences \\
\hline \multirow[t]{3}{*}{$1929-89$} & $I$ & -2.46 & $-4.25^{a}$ \\
\hline & $P S$ & -2.23 & $-4.56^{a}$ \\
\hline & $\lceil(X-M)+(G-T)\rceil$ & -3.15 & $-4.29 a$ \\
\hline \multirow[t]{3}{*}{$1929-72$} & $I$ & -2.83 & $-3.73^{b}$ \\
\hline & $P S$ & -2.12 & $-3.40^{c}$ \\
\hline & $\lceil(X-M)+(G-T)\rceil$ & -2.69 & $-3.42^{c}$ \\
\hline \multirow[t]{3}{*}{$1973-89$} & $I$ & -1.51 & $-3.58^{c}$ \\
\hline & $P S$ & -0.91 & $-4.70^{a}$ \\
\hline & $\lceil(X-M)+(G-T)\rceil$ & -2.04 & $-3.62^{c}$ \\
\hline
\end{tabular}

Note: I used Box-Pierce, Ljung-Box, and Lagrange Multiplier tests to verify that the error terms in all the regressions reported in this paper are not serially correlated.

Superscripts $a, b$, and $c$ indicate statistical significance at $1 \%, 5 \%$, and $10 \%$, respectively.

The $1 \%, 5 \%$, and $10 \%$ significance critical values for the Augmented Dickey-Fuller $t$-statistics are as follows: $-4.12,-3.49$, and -3.17 for the period $1929-89 ;-4.20,-3.52$, and -3.19 for the period 1929-72; and $-4.61,-3.71$, and -3.29 for the period 1973-89, respectively. These critical values are tabulated in MacKinnon (1991).

Notation: $\quad I=$ Domestic Investment, $P S=$ Private Saving, $X=$ Exports, $M=$ Imports, $G=$ Government Expenditure, and $T=$ Government Revenue. 
Table 3. Cointegration Test Results

\begin{tabular}{|c|c|c|c|c|c|c|c|}
\hline \multirow{2}{*}{$\begin{array}{l}\text { Sample } \\
\text { Period }\end{array}$} & \multirow{2}{*}{$\begin{array}{l}\text { Variables } \\
\text { Included }\end{array}$} & \multirow[t]{2}{*}{ Test } & \multirow[t]{2}{*}{$H_{0}$} & \multirow[t]{2}{*}{$H_{1}$} & \multirow{2}{*}{$\begin{array}{c}\text { Test } \\
\text { Statistic }\end{array}$} & \multicolumn{2}{|c|}{ Critical Values } \\
\hline & & & & & & $95 \%$ & $90 \%$ \\
\hline \multirow[t]{4}{*}{ 1929-89 } & $I, P S$ & $\lambda_{\max }$ & $r=0$ & $r=1$ & 10.64 & 14.06 & 12.07 \\
\hline & & & $r \leq 1$ & $r=2$ & 0.24 & 3.76 & 2.68 \\
\hline & & $J_{T}$ & $r=0$ & $r \geq 1$ & 10.88 & 15.41 & 13.32 \\
\hline & & & $r \leq 1$ & $r=2$ & 0.24 & 3.76 & 2.68 \\
\hline \multirow[t]{4}{*}{$1929-72$} & $I, P S$ & $\lambda_{\max }$ & $r=0$ & $r=1$ & $12.79^{c}$ & 14.06 & 12.07 \\
\hline & & & $r \leq 1$ & $r=2$ & 0.31 & 3.76 & 2.68 \\
\hline & & $J_{T}$ & $r=0$ & $r \geq 1$ & $13.40^{c}$ & 15.41 & 13.32 \\
\hline & & & $r \leq 1$ & $r=2$ & 0.31 & 3.76 & 2.68 \\
\hline \multirow[t]{4}{*}{ 1973-89 } & $I, P S$ & $\lambda_{\max }$ & $r=0$ & $r=1$ & 8.98 & 14.06 & 12.07 \\
\hline & & & $r \leq 1$ & $r=2$ & 4.42 & 3.76 & 2.68 \\
\hline & & $J_{T}$ & $r=0$ & $r \geq 1$ & 13.21 & 15.41 & 13.32 \\
\hline & & & $r \leq 1$ & $r=2$ & 4.42 & 3.76 & 2.68 \\
\hline
\end{tabular}

Note: Superscript $c$ indicates a $10 \%$ statistical significance.

The critical values are taken from Osterwald-Lenum (1992).

$\lambda_{\text {max }}$ is the maximal eigenvalue test statistic defined in (24).

$J_{T}$ is the trace test statistic defined in (25).

$r$ is the number of cointegrating vectors. 